\title{
Model-Based Waste Management Handling Angkuts Application to Smart City: The Perspective of Human Security
}

\author{
Elyta $^{\# 1}$, Garuda Wiko ${ }^{\# 1}$, Yulyanti Fahruna ${ }^{\# 1}$, Ishaq Rahman ${ }^{\# 2}$, Fuzy Firda Zhan ${ }^{\# 3}$ \\ \#1 Universitas Tanjungpura Indonesia \\ \#2 Universitas Hasanuddin Indonesia * \\ \#3 Social and Environmental Activists \\ *E-mail: ishaqrahman.unhas@gmail.com \\ Article History: Received: 11 January 2021; Accepted: 27 February 2021; Published online: 5 April 2021
}

\begin{abstract}
Security today is not only defined from a military standpoint, but also human security in which it has relations to social issues, human rights, economic, and environmental. Environmental issues, one of which is on the management of waste handling. A large amount of waste that goes to the place of final processing Pontianak Batu Layang is Hundreds of tonnes per day to make some millennials led by Muhammad Hafiz Waliyyudin initiating Angkuts application to support the city of Pontianak in waste management. This research used a descriptive method for designing a management model, especially waste management planning and actualization of Angkuts towards application-based Smart City from the perspective of human security. Based on these results, the researchers concluded that the design of waste handling management is done through planning and actuating. Planning applications applied technologies based on Angkuts industrial era 4.0 toward achieving smart city. Implementation of an application-based waste handling management Angkuts millennial generation is through participation and government support. As a recommendation, the application has the potential to support Angkuts based waste handling applications in the human security perspective to be used in a wider area again, not only in the city of Pontianak.
\end{abstract}

Keywords - Waste Management, Angkuts, Smart City, Human Security

\section{Introduction}

The security concept has undergone a change that originally focused on military security has evolved into human security. In that perspective, security is safe for the human condition itself and required as a comprehensive approach [1]. Further, it means that the man is safe from not a military threat, such as disasters, environmental degradation, pressure, torture, displacement, disease (such as HIV / AIDS, or SARS), also including the protection of rights. Thus, it's marks a shift in international relations, namely a change of norms about the relationship between state sovereignty to human security. Human security issues into social issues, human rights, economic, and environmental. One environmental issue is the issue of garbage.

Plastic waste is a major factor in the amount of garbage in the world [2]. This issue will certainly lead to the production of plastic waste will be growing every year.

Industry in the Russian state can demonstrate the level of market concentration that is relatively low [3]. In this case, the city of Pontianak should reflect on the state of Russia to realize the Smart City, which begins with these things. Since late 2018, the city of Pontianak has committed to becoming Smart City. This concept not only includes a single sector of administrative services but also covers many sectors starting from the economy (smart economy and business), social (social smart), infrastructure (smart infrastructure), education (smart education), and others, including the environmental sector (smart environment).

Smart City concept-based information technology (IT) is one of the supporting tools. It means that existing services can have a careful, effective, and efficient quick, easy, and of course, with minimal cost [4]. One way to strengthen the implementation of Smart City, the city government tried to integrate applications that already exist to facilitate the public. Talking about the application of the millennial in Indonesia has a very important role in it. Pontianak has no start-up, an application created by local youth to be a solution to environmental problems, especially solid waste. The application named Angkuts was initiated by the youth of West Kalimantan, Muhammad Hafiz Waliyuddin. Angkuts application concept is easier for people in charge of transporting waste without even actually paying officers to the community with a record of the waste is segregated garbage.

In addition to realizing the creation of a smart city in Pontianak, it is necessary to have public participation in the political world. It is useful to realize optimal development and by the wishes of the community [5]. And then, the planning on waste management is increasingly gained attention among practitioners for its ability to help companies address environmental problems. Management of this waste management plan involves activities such as green design, green procurement, environmental management total quality, environmentally friendly packaging, and community empowerment. Hence comes the inspiration initiated by Hafiz. Inspiration comes when Hafiz and his colleagues see the work of scavengers rather different from the others. Taking goods that can be said is not useful anymore for others. However, for scavengers, garbage instead of economic value. It also will provide a 
positive impact on them as well as reduce poverty. Reducing poverty is one of the important tasks [6]. Angkut's innovation was allegedly able to raise the living standards of scavengers.

Matters concerning the handling of waste have been the topic in three previous studies. Past research has discussed the handling of waste from the aspect of environmental management through the facilities or public infrastructure [7]. Another study discussed the set of indicators to address municipal solid waste collection systems taking into account leconomic performance [8]. Another study also addressed waste management by creating a garbage collecting robotruck model with the application of sensors to track the path and use Arduino software [9]. The renewal of the present study updates designing their management model-based waste handling applications from the perspective of human security. Based on this background, this study is to design from the perspective of human security of a management model, particularly waste management planning and actuating applications based Angkuts towards Smart City.

\section{Method}

This research was using descriptive method and the data regarding the management of human security, Angkuts application, and environmental problems in the city of Pontianak, Indonesia. Mechanical literature is a way to search for data and information by examining the documents related to the study. Sources of data and information came from Scopus indexed journal articles and internet electronic documents. The data in this study applied the stages, namely reducing the data, verifying the data, analyzing conceptual and rational, and making conclusions and recommendations.

\section{Results and Discussion}

\section{Design Model Management Planning in Particular Waste Handling Angkuts Based Applications to Smart City in Human Security Perspective}

\subsection{Planning Applications in Addressing Waste Angkuts}

Chronology of making an application begins with careful planning related to benefit by observing the strengths, weaknesses, opportunities, and obstacles for further formulation in the form of programs necessary for the intended purpose. From a management perspective of environmental issues, the integration of environmental concerns has focused over the last two decades [10]. Indonesia has a direct border with many countries, both bordering the land and sea area [11]. This focus appears given the close environment and the existence of human security. From the explanation above it can be seen that it aims to protect human security.

Human security is a case study of international development in focus to lead directly to human welfare that not only special views on construction statistics commonly used to measure the success of existing development. In providing security to its constituents, a functioning state should rationalize the problem as a threat or potential threat and allocate the available resources to respond to them [12]. The security provided must be complete, which consists of physical security and the safety of humans as social beings. The variables involved in the social security management perspective, social variables, politics, economics, technology, and the environment are available in the utilization Angkuts application.

Angkuts app idea originated from a young man from the area, Muhammad Hafiz Waliyuddin, a student of Computer Science Faculty of Engineering, the Universitas Tanjungpura Pontianak, who has served as Chairman of the Executive Board (BEM) Faculty of Engineering, Universitas Tanjungpura Pontianak. Hafiz and colleagues managed to create an application-based trash hauler android named Angkuts. Before being named Angkuts, he and his colleagues had named this application to the Trash Grab name. However, there is a change in the name to the language, more contemporary style, and millennial. The study found that this application resembles Waste Bank and adds a touch of digital technology so that the users can enter the data and garbage into information to customers regarding the price paid to them. The price totaled at each pick-up trash is different from customers who cash virtually following the applicable terms and conditions. The garbage is then being picked up by the "Angkuts" (the name to those who pick up trash Angkuts customers) then handed over to collectors.

Besides, one thing that can be used as a guide to making this Angkuts application better is to pay attention to the little things that are useful for strengthening the sense of solidarity and nationalism in the community. We can take examples of woven crafts made by women in large border regions that are useful for improving the community's economy, also, it is useful to strengthen their sense of solidarity and nationalism [13]. This Angkuts application should reflect on things these things, in addition to improving the economy, but also to strengthen the sense of community solidarity and nationality. 
Hafiz as the founder and Director of the Company of Angkuts Indonesia were told that the services of transporting waste to the application Angkuts include inorganic waste which was later purchased from the customer the old newspapers $(\mathrm{Rp} 500,00 / \mathrm{kg})$, plastic bottles $(\mathrm{Rp} 800,00 / \mathrm{kg})$, a glass of mineral water plastic $(\mathrm{Rp} 1.000,00 / \mathrm{kg})$, aluminum cans (Rp6.000,00/kg), cardboard (Rp500,00/kg), paper (Rp500,00/kg), and others. The business model developed by Angkuts this time is in the form of the stakeholder management application. It is the government's feature to manage residents' trash, not only transport garbage from the houses but also to cooperate with the government and other parties such as private and schools. In the future, the government can make Angkuts as management applications in waste management from relevant agencies, namely the Department of the Environment.

Angkuts' vision is to make people see that the garbage that has value. Angkuts has implemented additional value in the trash or scavengers in support of the smart city. This vision is certainly large, thus requiring a long time, which ranges from 5 to 10 years to achieve. The necessary steps to do at an early stage are connecting people and the trash center. Angkuts is an attempt to resolve these problems and then grows with a variety of challenges to finally be known widely and get a variety of national and international recognition.

\subsection{Human Security: Millennial Generation Actuating Angkuts Based Applications in Managing Waste}

Actualization on management is implementing programs to achieve the goals set [14]. Achievement of these objectives pays attention to the rapid development of technology today, thanks to the invention of the internet and its applications in the industrial sphere. It certainly should be supported by qualified human resources as well as the millennial generation [15].

Moreover, in the era of digitalization, the internet is required [16]. Internet is a popular millennial generation (Generation Y), the generation that grew up in a dynamic environment through advanced technology. Properties owned by this generation vary depending on the environment, family, and social life in the surrounding areas. Interaction patterns in the millennial generation are also more open communication, in contrast with previousgeneration. Not only on social issues but also economic and political issues. So do not be surprised if the millennial generation also looks very reactive to environmental changes occurring around them, including 4.0 entering the industry today. This fact proves that these adult roles and creativity of the millennial generation is needed because the industrial era 4.0 is already in sight,

Industry 4.0 is the fourth stage of the development of the world revolution. The three stages before the industrial revolution 4.0 are (1) 1.0 Industrial Revolution made into innovations to the production of goods in bulk; (2) the industrial revolution 2.0 regularly to suppress the price of production; and (3) 3.0 Industrial Revolution in 1970 was characterized by the use of computerized technology [17].

Angkuts application begins with Hafiz's participation as the millennial generation, due to problems of waste that gave birth to an innovation that benefits as a civil society by implementing computerized technological advances. Today, much of the literature shows a significant breakthrough in developing digital technology [18]. This breakthrough for the millennial useful to be able to think creatively to create innovation and be more active in exploring it. Most people are trying to explore the effects of technology and social initiatives from around the world [19]. From this statement, Muhammad Hafiz Waliyuddin, including one of them to create innovations that benefit the community.

The use of digital technology in governance has skyrocketed over the past two decades. It surpasses all of Sustainable Development Goals and has an important role in human development, where one point is that climate action brings the issue of environmental protection. Digital technology has the potential to change not only the public service by the government but also related to the management of the waste problem efficiently [20]. The development of digital technology is the reason for the cause of social change that comes from the device or platform [21]. The device or the platform can eventually become an online-based large enterprise, known as a startup company.

The characteristics of companies have a classification as a start-up company from 4 dimensions: (1) Organizational, namely the organization of small-scale, dominated organizationally young, environment organization homogeneously, the organizational structure in the form of informal, have a little difference in the organization, and the organization is centralized; (2) Ownership, the relation between owner and managers in decision-making, as well as the supervision, conducted directly; (3) Strategy and Innovation, including the use of grooved marketing strategy, oriented towards risk, rapid innovation, as an activator of the first or second, and the lack of research products; and (4) Funding from personal savings or a family [22].

In a pioneering start-up, a stable system of reference is necessary. The stability of the power system is an important problem in the security of the operating system since the 1920s [23]. In a start-up company pioneering the necessary cooperation, the cooperation is often seen in the process of production actuating the employees and 
social relations [24]. These explanations aim to break down development in every region in Indonesia, both urban and rural regions.

The rapid growth of development in urban areas in Indonesia, followed by an increase in the displacement majority of rural people to the cities included in Pontianak is also indeed impacting on increasing the number of city dwellers that are also comparable with the waste generated. Besides, the city of Pontianak is a city of trading services that makes it solid with the routine of daily buying and selling of people-produced waste. If not handled properly, this issue will certainly have a serious impact that is not only in environmental terms but also in terms of health and social services.

With the application of this, Angkuts will certainly provide a positive impact on the waste problem in the community if the vision and mission can be run well and run with the actualization of the synergy between the public (in this case, the millennial generation) and the government. Hafiz said that the TOR) of the government. Angkuts role as a young innovative bid to support the government ready to run services and data collection system based on e-government and smart city destination.

The results of the research revealed welcomed and appreciated innovation Angkuts of Hafiz. Angkuts rated Pontianak City Government can help in addressing the waste problem. Hfiz and his colleagues could think of making the inorganic trash that had been the source of the problem and then turns into economic value.

Sub Division of Administration Technical Services Unit of final processing places Batu Layang Pontianak, Lita Luki Bresti, reveals that startup is considered more modern than the waste bank. Also, the application Angkuts provide convenience to the public so as not to bother anymore when taking out the garbage and even changing people's mindset that garbage is not an issue, and it has economic value and yield.

The amount of waste in the landfill Batu Layang Pontianak rises due to the additional 50 tons of transport by Angkuts application. Thus the production of waste in the city of Pontianak could be more than that, given the cultural life still throws garbage into the river. The public can familiarize environmentally friendly lifestyles by applying the principles of the 3R (Reduce, Reuse, and Recycle). It has been able to add value to the household. Money earned by customers from the utilization Angkuts application can work as everyday community life, including paying PBB (Land and Building Tax) and thus contributing to the welfare of society. The function of human security is also to raise the issue of environmental change on top of other policy issues, including the welfare of the community. Thus, the description of model particular management planning and actuating based waste handling Angkuts towards Smart City applications from in security perspective is as follows.

Figure 1. Waste Management Model-Based Applications Angkuts

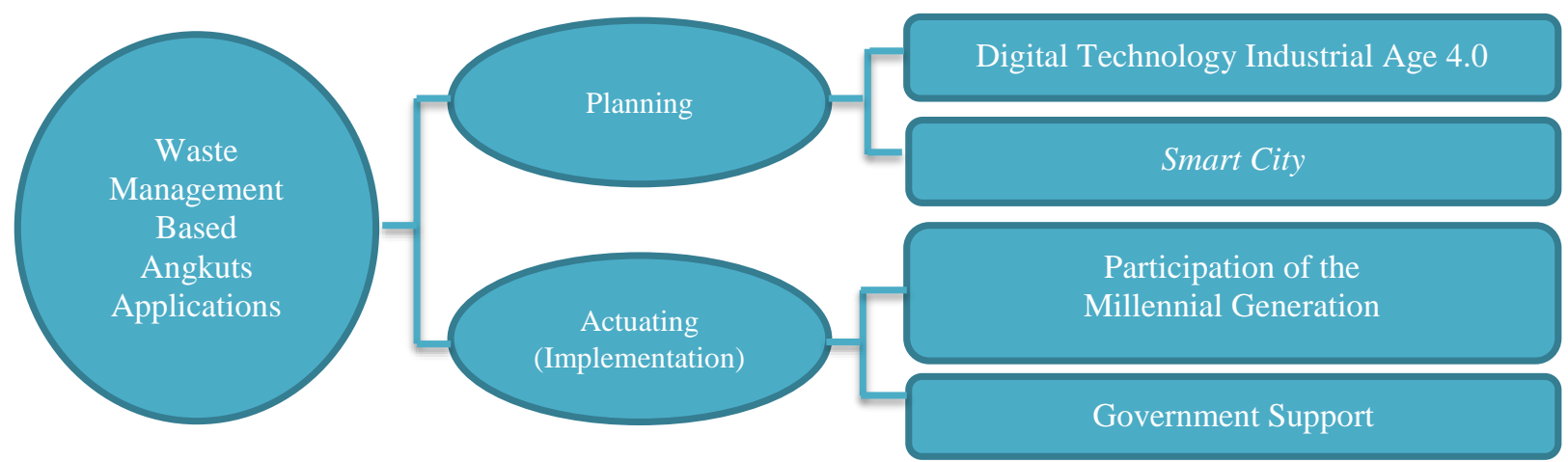

Source: Adapted by the researchers, 2019

Angkuts customers also get the benefit from this startup. According to Zahrul, Angkuts was a solution that optimizes efforts to achieve Pontianak city clean and green. The achievement of Angkuts brought by Hafiz and colleagues fairly is very remarkable. Angkuts managed to win several competitions startup. Call it the Socio Digi Leader 2016 The Next Dev, Astra Start-Up Challenge, and a competition held by the Geospatial Information Agency successfully put Angkuts in the ranks of finalists, even a winner. US ambassador to Indonesia has ever invited Hafiz along with five other founders of start-ups to Washington in the Creative Economy and entrepreneurship Incubators. 


\section{Conclusions and Recommendations}

Muhammad Hafiz Waliyuddin, the West Kalimantan youth who has found innovative solutions to the problems of waste that is through Angkuts application. It exports scavengers who brought the concept turned out to be a very necessary thing not only by society but also by the government, private, and even educational institutions such as schools. Reflecting on the story of Hafiz and the application Angkuts this creation, the youth should be able to grow its social sensitivity to the community. The millennial must respond and innovate in order not to go crazy amid the brunt of the industrial era 4.0 today. Design management model based on waste handling Angkuts application to the Smart City in the perspective of human security consists of planning and actuating the millennial generation through participation in it. Thus, to grow Angkuts application, also can work with all governments on a wider scope. So the millennial generation can share their thoughts on solving the waste with more people.

\section{References}

[1] UN, "Human Security in Theory and Practice : Application of the Human Security Concept and the United Nations Trust Fund for Human Security," 2009.

[2] P. Wu et al., "Environmental occurrences, fate, and impacts of microplastics," Ecotoxicol. Environ. Saf., vol. 184, no. April, p. 109612, 2019.

[3] D. Trubnikov, "The Russian Telecommunications Experience: a Positive Outcome of the Competitive Order in the Industry,” J. Ind. Compet. Trade, vol. 20, no. 1, pp. 35-58, 2019.

[4] N. Millner, "As the drone flies: Configuring a vertical politics of contestation within forest conservation," Polit. Geogr., vol. 80, no. 1, pp. 1-13, 2020.

[5] Z. Zulkarnaen, and E. Elyta., "Political Participation of Border Communities at Sajingan Besar in Election of Representatives Area," pp. 39-45, 2014.

[6] M. Malul, "Poverty and Social Policy: Perceptions Versus Reality," Poverty and Public Policy, vol. 11, no. 4, pp. 291-301, 2019.

[7] E. Amasuomo and J. Baird, "The Concept of Waste and Waste Management,” J. Manag. Sustain., vol. 6, no. 4 , p. $88,2016$.

[8] G. Bertanza, E. Ziliani, and L. Menoni, “Techno-economic performance indicators of municipal solid waste collection strategies," Waste Manag., vol. 74, pp. 86-97, 2018.

[9] B. Akshaya and K. Selvakumar, "Innovative waste management technique via garbage collecting robotruck,” Int. J. Recent Technol. Eng., vol. 8, no. 2, pp. 272-277, 2019.

[10] A. Shamsuddin, E. Wahab, W. Nurul, K. Wan, and N. H. Abdullah, "Green Supply Chain Management ( GSCM ): A Research Agenda,” vol. 9, no. 1, pp. 1100-1104, 2020.

[11] Elyta, H. Almutahar, and Z. Saing, "National Strength on Construction of International Freight Terminal in Entikong Indonesia,” Int. J. Sci. Technol. Res., vol. 8, no. 3, pp. 10-15, 2019.

[12] A. A. Wibisono, "The Impact of Democratization and International Exposure to Indonesian CounterTerrorism,” Glob. J. Polit. Int., vol. 19, no. 2, pp. 138-155, 2017.

[13] Elyta and A. Razak, "The Role of Weavers Woman in Strengthening Nationalism (Case Study in Sajingan Besar Frontier, Indonesia)," Sosiohumaniora, vol. 21, no. 1, p. 40, 2019.

[14] T. W. Maduretno and L. Fajri, "The effect of optimization learning resource based on Planning, Organizing, Actuating, Controlling (POAC) on contextual learning to students' conceptual understanding of motion and force material," J. Phys. Conf. Ser., vol. 1171, no. 1, pp. 1-7, 2019.

[15] A. Gelb, V. Ramachandran, C. J. Meyer, D. Wadhwa, and K. Navis, "Can Sub-Saharan Africa Be a Manufacturing Destination? Labor Costs, Price Levels, and the Role of Industrial Policy,” J. Ind. Compet. Trade, 2020.

[16] C. J. Boudreaux, "The Importance of Industry to Strategic Entrepreneurship: Evidence from the Kauffman Firm Survey,” J. Ind. Compet. Trade, 2019.

[17] K. Schwab, The Fourth Industrial Revolution. Switzerland: World Economic Forum, 2016.

[18] T. Wright and E. Benoit, "Technology Use in Designing Curriculum for Archivists: Utilizing Andragogical Approaches in Designing Digital Learning Environments for Archives Professional Development," Preserv. Digit. Technol. Cult., vol. 48, no. 2, pp. 85-94, 2019.

[19] R. Belot, Y. Bergman, H. J. Braun, J. Hadlaw, S. Poser, and M. Zdrodowska, "Forty-fifth Symposium of the International Committee for the History of Technology: 'Technological Drive from Past to Future? 50 Years of ICOHTEC,' Jean Monnet University, Saint-Étienne, France, 17-21 July 2018,” Technol. Cult., vol. 60, no. 4, pp. 1083-1092, 2019.

[20] J. Chauvin and M. Lomazzi, "The digital technology revolution and its impact on the public's health," Eur. J. Public Health, vol. 27, no. 6, p. 947, 2017. 
[21] D. Miller, “Anthropological studies of mobile phones,” Technol. Cult., vol. 60, no. 4, pp. 1093-1097, 2019.

[22] R. Nurcahyo, M. I. Akbar, and D. S. Gabriel, "Characteristics of startup company and its strategy: Analysis of Indonesia fashion startup companies,” Int. J. Eng. Technol., vol. 7, no. 2, pp. 44-47, 2018.

[23] C. Andersson, J. E. Solem, and B. Eliasson, "Classification of power system stability using support vector machines,” 2005 IEEE Power Eng. Soc. Gen. Meet., vol. 1, no. 2, pp. 650-655, 2005.

[24] F. Afridi, A. Dhillon, S. X. Li, and S. Sharma, "Using social connections and financial incentives to solve coordination failure: A quasi-field experiment in India's manufacturing sector,” J. Dev. Econ., vol. 144, no. April 2019, pp. 1-13, 2020. 